\title{
ART THERAPY IN ONCOLOGY AND PALLIATIVE CARE - OVERVIEW OF EMPIRICAL RESULTS AND A CASE VIGNETTE
}

\author{
Harald Gruber \\ Alanus University of Arts and Social Sciences, Germany
}

\begin{abstract}
Research background. In the spectrum of psychotherapeutic interventions, artistic therapies such as painting, clay modelling, music, dance therapy, as well as poetry and bibliotherapy have become an essential part of psychosocial treatment in a wide variety of medical and therapeutic indications. Artistic therapies enable patients to express stressful emotions in a protected environment, to regulate their own experiences, to learn about resources and to better process the psychologically restrictive consequences of the illness. Empirical evidence of efficacy is still lacking in many fields of Arts Therapies. However, recent, partially controlled randomized studies on art therapy in oncology show a significant reduction in anxiety and depression, a lesser degree of experiencing stress, improved perception of health, and improved disease management. A case Vignette shows how sustainable artistic experiences can have a therapeutic effect and how significant they can become for the individual client.

Conclusion. Art therapy, especially in the field of oncology and palliative care, offers special opportunities for therapeutic accompaniment, through which central objectives can be met in the context of the overall treatment. It requires further practical and scientific development work as well as good public relations in order to draw attention to the potential of art therapy and to further validate and establish it as a fixed therapeutic component in oncology and palliative medicine, both inpatient and outpatient.
\end{abstract}

Keywords: art therapy, oncology, palliative care, case report.

\section{INTRODUCTION}

A cancer diagnosis is generally a big stress for those who are affected. Although improving treatment options has prolonged the survival time for most types of tumor entities, complex and long-lasting medical therapies for patients are often associated with major mental and physical stress from treatment and so-called post-treatment complications.

The focus is on the threat of death, the violation of physical integrity, the loss of autonomy, the loss of activities, social isolation and the threat to social identity (Weis, 2002). The psychosocial offers that have been developed in a variety of ways over the past two decades are today widely studied and, in summary, provide proof of effective and necessary support (Faller et al., 2013).

The goal of psycho-oncological measures is to support the patients in the treatment of diseases and to provide assistance for the psychological management of 
the disease and the resulting secondary problems. Here, the improvement of the quality of life of those affected is in the foreground.

Artistic therapies in oncology and palliative care. In the spectrum of psychotherapeutic interventions, artistic therapies such as painting, clay modelling, music, dance therapy, as well as poetry and bibliotherapy have become an essential part of psychosocial treatment in a wide variety of medical and therapeutic indications (Dannecker, 2003). In the field of oncology and palliative care, in recent years a variety of publications have highlighted the potential of artistic therapies and their particular benefits to patients in this field.

As explained in more detail below, the growing body of research from the past 15 years clearly indicates that these therapeutic offerings have an effect both in individual case studies and in larger scale intervention studies. The level of knowledge is, however, not yet sufficient to guarantee a security of supply in the current health policy situation.

Artistic therapies in oncological rehabilitation. An important aspect of the psycho-oncological offer in rehabilitation is the support in coping strategies of the patients. It is expressed in the desire of many cancer patients to be actively involved in doing something for themselves, to regain the psychological control and thereby to contribute something to their own recovery. In recent research literature this has been elaborated in the concepts of self-efficacy and patient competence (Giesler, Weis, 2008) and has also been included in the National Cancer Plan in the field of patient orientation.

Artistic therapies enable patients to express stressful emotions in a protected environment, to regulate their own experiences, to learn about resources and to better process the psychologically restrictive consequences of the illness. In addition, they help to strengthen their competence and promote their own healthy shares (Henn, Gruber, 2004; Wormit, 2008).

The high willingness of those affected with artistic / creative means to contribute to their recovery, or their psychological stabilization, for various reasons. One is the search of sick people for an expression of their experience in a life-threatening or apparently life-threatening situation (Sinapius, 2009). Furthermore, as shown comprehensibly in various publications, they would like to engage in creative activities or be accompanied by art therapy, even if this has so far played no role or only a subordinate role in their lives (Henn, Gruber, 2004).

These raises the question of why people, when they are seriously ill, often seek out the means of creativity on their own or are encouraged to take an active role in shaping it. P. Sinapius (2013) writes: "By expressing ourselves in artistic forma- 
tions of our need, we create places where suffering - and life - is possible under human conditions".

As a result of his investigation (Sinapius, 2013), artistic expression offers specific possibilities of coping, which are structured as follows:

- defence and search for support and orientation,

- becoming aware and hoping,

- dealing with yourself,

- reconciliation, integration and farewell.

So far, however, it is unclear which patients benefit from which artistic therapy, since no scientifically comprehensible criteria have been developed for whether the respective medium makes a differential indication possible with regard to its specific efficacy. As many experiences from the practice of oncological rehabilitation show, a large proportion of oncological rehabilitation seeks a way to artistic-creative expression by working with artistic therapies. Again and again, it is observed that, despite sometimes very negative biographical experiences in connection with an artistic medium (for example auditions at school), those concerned are prepared to deal with an artistic medium. It begs the question what leads to this impressive and counterintuitive readiness.

Frequently, patients report in advance their wishes and ideas to try something new, to experiment or to deal with the unknown. Despite this uncertainty and the associated fears, people dare to embark on an adventure of self-exploration after a cancer, with the question of experiencing, their own actions and their effect on them as well as their current environment.

In their understanding as experiential and action-oriented forms of psychotherapy, artistic therapies make use of the choice of materials and forms of expression of the visual (primarily painting and sculpture) as well as the transitory arts (primarily music and dance). As the clinical experience has shown for many years, the artistic therapies give people with cancer the opportunity to express their feelings and thus to improve their self-perception, to specifically experience relaxation, to improve communication, to reduce pain, or to work on the body image. They are motivated by the artistic therapies to contribute themselves to their recovery. Patients feel more involved in their treatment and are helped to actively regulate their stress disorder as part of the disease. Active activity offers the possibility to the patient.

Empirical studies on art therapy in oncology. Art therapy with visual media is a much less systematically examined discipline in oncology compared to music therapy. Despite the fact that the field has been very differentiated from the theo- 
retical and methodological point of view for several decades (Dannecker, 2003), empirical evidence of efficacy is still lacking in many fields of application.

However, recent, partially controlled randomized studies on art therapy in oncology show a significant reduction in anxiety and depression, a lesser degree of experiencing stress, improved perception of health, and improved disease management (Monti et al., 2006; Öster et al., 2006; Reynolds, Prior, 2006; Bar-Sela et al., 2007; Svensk, 2009).

Several single-subject art therapy studies and case reports with oncology patients have shown how art therapy contributes to improved communication; reduce negative symptoms, and leads to an increased experience of strength (Luzzatto et al., 2003). Further studies with breast cancer patients point to the efficacy of art therapy in expressing feelings and thoughts (Borgmann, 2002) and in dealing with the disease to go a way of individual "finding meaning" (Collie et al., 2006). In a current cohort study, S. Forzoni et al. (2010) with a larger group of patients ( $\mathrm{n}=$ 157) demonstrated the specificity of the artistic process and non-verbal communication.

A newer systematic review (Wood et al., 2011) summarized the evidence-based study of symptom management by art therapy in adult cancer patients. For this purpose, 12 studies were carried out using both qualitative and quantitative methods. The authors conclude that art therapy as a psychotherapeutic method contributes to the improvement of treatment-related symptoms (anxiety, depression) and to support the process of psychological adaptation to the disease (quality of life) and at the same time indicate the urgent need for research, also because of previous studies with too little case numbers. Currently, this is confirmed in a systematic review with meta-analysis (Boehm et al., 2014) for all artistic therapies, but only for the significant reduction of anxiety.

Empirical studies on art therapy in palliative medicine. Four recent prospective intervention studies investigated the effect of art therapy treatment in advanced cancer patients (Lin et al., 2012, Rhondali et al., 2013; Lefevre et al., 2016) with different methodological approaches examined. In a sample of 177 , Lin et al. showed through structured interviews that $70 \%$ of patients felt more relaxed after art therapy, $53.1 \%$ felt physically better and $80 \%$ had positive memories (Lin et al., 2012). In their study, Lefèvre and colleagues confirmed the positive findings of the improvement of pain, fatigue, anxiety, and well-being (Rhondali et al., 2013) in the symptomatic areas of ESAS in a group of 22 patients (Lefevre et al., 2016). The change in aesthetic experience was examined in correlation with the individual symptoms. Using a scale (0 to 10) of the Harmonic Cube (Forestier, 2004), they presented the extent of experienced wellbeing during artistic creation (good), positive pride (close to self-efficacy) (well), and beauty as aesthetic emo- 
tion (beautiful) during and after the art therapy intervention. The results showed large effect sizes in the correlations of well-being, pride and beauty with pain reduction; Well-being and pride with anxiety reduction; Feeling of well-being with a reduction in the feeling of illness; Proud with a reduction in sadness and depression, as well as a sense of well-being with the Distress Total Score.

In another oncology study (Laridon-Valentini et al., 2015), the effects of art therapy between palliative and non-palliative patients were differentiated. A group of 80 oncological patients was examined. There were significant effects on symptoms and quality of life regardless of the stage of the disease. There were only differences in the area of fatigue, where improvements in palliative care were significantly more pronounced than in non-palliative care, with a worse / more tired initial situation. Overall $(\mathrm{N}=80)$, a majority of patients $(90 \%)$ experienced art therapy as a distraction / attention-grabber to something positive, and $89 \%$ as calming and relaxing. For the Long-term Effects (HADS), World Health Organization Quality of Life, Short Version (WHOQOL-BREF)) improvements in the overall quality of life and anxiety reduction group were significant at $60 \%$, but not in pain.

Case vignette of a patient in oncological rehabilitation. Many people seek rehabilitation after acute treatment (surgery, chemo, radiation) of their oncological disease. The focus here is on the treatment of physical problems, social questions, such as the return to work and further support in the context of psycho-oncological services. These offerings aim at maintaining or restoring quality of life and improving disease management (Gruber et al., 2011).

Patients predominantly and understandably come to the rehabilitation with the goal of "getting well again". For a large part of the patients, it is possible to expect further treatment in order to further reduce the disease. A smaller part must start with a diagnosis of a limited lifetime. This initial palliative treatment situation is a difficult moment for patients, especially when they are still younger. It is also a challenge for the therapist since treatment time in rehabilitation is usually limited to three or four weeks. To this end, a usually comprehensive rehabilitative treatment plan of physiotherapeutic, sports therapy, nutritional therapy, social law and psycho-oncological measures prescribes a treatment framework in which it is also necessary to clarify with the patient which significance of the respective measure is to be awarded. Against this background, the following case vignette would like to show which possibilities in this particular case opened up the art therapy offer and how this was used by this patient.

At the same time, the presentation does not want to be understood as a model. Rather, we try to make it comprehensible on a case-by-case basis how the art-therapeutic process of a patient with an advanced tumour disease makes it possible to clarify specific questions that can be seen in a larger context of palliative care. 
In addition, the frame of the presentation only allows a sketch of the entire treatment to be sketched. An impression should be given of how, in the context of rehabilitation, access can be made possible with artistic and therapeutic means in this initially seemingly palliative disease situation. The art therapy treatment is presented to a patient who was admitted to inpatient oncological rehabilitation shortly after medical acute treatment.

The case was also chosen because it stands out in a special way from the other cases. It should be clarified, which experiences people can go through in an artistic-therapeutic process. How the accompanying artistic activity opens up opportunities for experiencing and understanding how to deal with the disease, which otherwise would seem difficult to access.

Special features of this therapy history:

Nine years after treatment in rehabilitation, a client contacted a touching letter, summing up her experiences in art therapy in an unsolicited and retrospective fashion. During this time there was no contact with the client. Due to a job change on my part, she had to make the effort, despite her obviously only limited lifetime, to find my professional address to send me a letter.

She introduces her letter, which I received in the summer of 2014 (here quoted verbatim in excerpts), with the following words:

"[...] when you were still in the clinic [...] I was one of your many patients in painting therapy. You will hardly remember me, which is not so bad [...]"

My prognosis was bad. Like so many others in this situation, I lost my footing and literally fell to the ground. I was not able to grasp or even put into words what happened to me. [...] Also, when I know that my powers are running through my fingers and my time to leave has come soon. I found my peace. I had nine full years to find my way. But I would not like to tell you that, but to thank you for the good and important painting therapy that saved my life. [...] I have realized that I have to start spinning the net deep down in the abyss to stop my fall. And besides, I have gradually miraculously found my words again, words to describe and communicate. That is with your merit. That is why I want to send you a poem that came out years later $[\ldots]$ "..

Excerpts from the art therapy course:

Anamnesis: 30-year-old patient; married; by profession as a doctor, employed in a clinic.

Diagnosis: In the early summer of the year, she was diagnosed with extensive liver cell carcinoma with an unfavorable prognosis (HCC pT3 pN0 M0, G3).

Treatment: Surgical removal of the spleen, partial resection of the peritoneum, diaphragmatic resection, liver resection and liver segment resection. 
Rehabilitation stay: In the late summer of the year, she was still clearly drawn by the consequences of the extended surgery, nevertheless in a good general condition for the oncological rehabilitation measure. She was very interested and open to the various therapeutic offers of the clinic and very much wanted to get to know art therapy. She had not developed any other artistic skills or experience with art therapy other than the regular school experience and the joy of creativity. The desire to paint, like some other patients, she had explicitly not. Her personal goal was to use a non-linguistic medium for herself and her situation.

On request, she was able to assess her condition very well and realistically, from a medical - therapeutic point of view, against the background of her job, as well as through questions from colleagues. She knew that she was very likely to have a very limited life perspective.

General goals of art therapy, as described in the context of disease management in oncological patients in six core dimensions:

- restore competence experience; Gain control; Enable and activate action; Establish a relationship; realistically assess the situation; reduce stress emotionally and somato-psychologically (Vollmer 2004).

Art therapy course. In the first meeting, the patient was open-minded and open to the possibilities of art therapy.

After a short introduction to the handling with watercolours, she painted a free, spontaneous picture. She also becomes, in a way that is amazing for me again and again, as many other patients, without any great hurdles aesthetically active, creatively active. It is no hindrance, not a long search or uncertainty to experience. It seems to be a great openness to the occurring creative events. She does not need or seek any support from me; goes straight to their colour choices of intense colours as blue, yellow, and some orange-red. In the joint picture discussion, she immediately saw pictorial characteristics in relation to herself and her character traits: "I am a very straightforward person; I like symmetries and I like to keep track. Because of this other people often see a strong side in me, even if it looks very different inside. In the next session, I will paint a different picture." After a joint viewing she decides to paint in the next therapy session "more from the direct experience".

In these few words, a level of self-encountering becomes clear, which on the one hand names an emotional level of experience emanating from the consciousness and on the other hand directly implies an artistic developmental step. In this first hour, she seems much focused, able to regulate her actions in the process. She does not seek an outward form of a specific pictorial result, but actively seeks an autotelic action space in which spontaneous action and deliberate contention meet together. 
At the beginning of the second session she is irritated because she cannot find a beginning, she has no "idea". "I do not know how it works"; something in her is reluctant. She had something in her mind but she did not know how to tackle. It was not my role as a therapist to offer her a possible way. She struggled for something "different", perhaps also for something "new". This attempt I had to accompany.

After a short conversation, she finds a start, in which she does not give up formal control with the use of a thin brush. The fine brush helps her draw fine lines at the beginning, not to apply too much colour at once, to build up the image slowly, to walk step by step and to keep control over the image formation process with which she "capture new land". The result is a dynamic composition, which she later transforms with wide paintbrushes into an overall complex pictorial space. Deepened, she "forgets" the time (flow experience). She must be reminded of the approaching end of the hour. In terms of content, she delves into a symbolic pictorial space that opens up many opportunities for association and interpretation. A great figure and its position in space, the relationship of the different figures to each other; Topics such as protection and security become clear; being thrown as a human is being into a space is pictorially addressed. She lets herself be touched by the picture and names the wish: "coming more to my inside".

After a consultation with the other accompanying therapists she seemed stable enough for the argument on a previously rather unknown terrain, the inner encounter with her life-threatening illness. At the end of the third hour she reported: "the picture guided me; I did not feel I could control it".

The picture has touched her very much, without directly and consciously being able to perceive in the therapy session, what caused the touch. The next day she arranged an additional single therapy session to discuss the picture with me again. She reported from a great restlessness after the therapy session. She reported from a long walk "on which I lost my way and could only find the way again after several hours". She described a feeling of extreme loneliness as well as thoughts of suicide, which are not relevant at the moment. Several times her inner images of dying and suffering people from their professional experience came into her mind, which raised the question of a self-determined end in her life, so as not to suffer, if it came to that. Nine years later, she sends me an excerpt from her diary:

"This dense fog in the forest - you could say my illness lies like this fog over me. When looking into the distance, contours of the spruce with their spiny, vertically projecting branches become increasingly blurred, and then merge entirely into a greyish-white wall. Even treetops lose themselves in the glistening white. I can only guess where my way leads. He seems to disappear in the void. It is scary. At the same time, however, there is a wonderful, almost peaceful peace. There seems to be life somewhere behind the fog. I focus on my immediate environment. 
I discover a yellow flower along the way and a yellow-black spotted leaf. I admire grown moss on the rock like a map. Maybe it's actually helpful to live the moment, if the looking into the future right now has no perspective."

In further pictures, which cannot be described in detail here, she deals artistically, for example with questions, how she can deal with difficult as well as good thoughts at the same time. In addition, she discovers her formerly very emotional affinity to horses in a freely designed picture and therefore decides to resume her after her stay in the clinic.

In a later picture, her point of view is "social closeness". How she communicates with others and how she believes others perceive and understand her. At the same time, there is something caring about in the picture, an affection in which gestural protection is expressed. Without naming it directly in this hour, she reports a year later, during another rehabilitation stay in music therapy, of a clear desire for children, which should come true two years later. Despite knowing the limitations of her life, she and her husband had deliberately made a decision for a child.

\section{DISCUSSION}

This small case vignette was intended to show how sustainable artistic-experiences can have a therapeutic effect and how significant they can become for the individual client. This patient was impressively able to understand how, in a lifethreatening disease situation, the goals of activating resources, dealing with illness, death and dying, searching for meaning and spirituality, and communicating with the social environment could be followed very well by art therapy. The pictorial expression each showed her a way of dealing with herself, which was primarily not intended verbally, but in the visual explained questions that triggered a central moment of self-encounter with different content. It is in no case an exemplary path that could equally apply to others, but rather a search for identity in the encounter with the limited life of this person.

One of the main potentials of art therapy lies in the specific possibilities of aesthetic-creative expression methods and their ability to adapt to different requirement levels. As the psychotherapist and art therapist, Dreifuss-Kattan described in 1990 how art therapy, through the rediscovery of creativity in the face of a life-threatening disease, is not only a mouthpiece of suffering, but also a means of overcoming it (Dreifuss-Kattan, 1990). Especially in relation to the existential life situation, it is of particular advantage that on active- or receptive-shaping experiences, primarily non-verbal forms of communication and expression are offered that can initiate sensory-aesthetic design processes in which patients experience, for example, immediate distraction and relaxation. Patients, in spite of their advan- 
ced suffering, can become autonomously creative, express their fears, burdens, desires and needs, engage in creative interaction with others and, on this basis, also work on biographical issues. These special possibilities of art therapy are often described by practitioners and confirmed in qualitative and quantitative investigations on the basis of structured patient surveys.

\section{CONCLUSION}

In conclusion, it should be noted that art therapy, especially in the field of palliative care, offers special opportunities for therapeutic accompaniment, through which central objectives can be fulfilled in the context of the overall treatment. However, the establishment and integration of art therapy and comparable offers would optimally fit into a holistic palliative offer, as the authors of the above-mentioned US-wide cross-sectional study summarized (Dain et al., 2015). It requires further practical and scientific development work as well as good public relations in order to draw attention to the potential of art therapy and to further validate and establish it as a fixed therapeutic component in palliative medicine, both inpatient and outpatient.

\section{LITERATURE}

Bar-Sela, G., Atid, L., Danos, S., Gabay, N., Epelbaum, R. (2007). Art therapy improved depression and influenced fatigue levels in cancer patients on chemotherapy. Psycho-Oncology, 16 (11), 980-984.

Boehm, K., Cramer, H., Staroszynski, T., Ostermann, T. (2014). Arts therapies for anxiety, depression, and quality of life in breast cancer patients: A systematic review and meta-analysis. Evidence-Based Complementary and Alternative Medicine, 2014. http://dx.doi.org/10.1155/2014/103297

Borgman, E. L. (2002). Art therapy with three women diagnosed with cancer. The Arts in Psychotherapy, 29 (5), $245-251$.

Collie, K., Bottorff, J. L., Long, B. C. (2006). A narrative view of art therapy and art making by women with breast cancer. Journal of Health Psychology, 11 (5), 761-775.

Dain, A. S., Bradley, E. H., Hurzeler, R., Aldridge, M. D. (2015). Massage, music, and art therapy in hospice: Results of a national survey. Journal of Pain and Symptom Management, 49 (6), 1035-1041. doi: 10.1016/j. jpainsymman.2014.11.295

Dannecker, K. 2003. Internationale Perspektiven der Kunsttherapie. Graz: Nausner.

Dreifuss-Kattan, E. (1990). Cancer Stories: Creativity and Self-repair (Vol. 11). Lawrence Erlbaum Assoc. Incorporated.

Faller, H., Schuler, M., Richard, M. et al. (2013). Effects of psycho-oncologic interventions on emotional distress and quality of life in adult patients with cancer: Systematic review and meta-analysis. Journal of Clinical Oncology, 31 (6), 782-793.

Forestier, R. (2004). Tout Savoir Sur L'art Occidental. Favre.

Forzoni, S., Perez, M., Martignetti, A., Crispino, S. (2010). Art therapy with cancer patients during chemotherapy sessions: An analysis of the patients' perception of helpfulness. Palliative \& Supportive Care, 8 (1), 41-48.

Giesler, J. M., Weis, J. (2008). Developing a self-rating measure of patient competence in the context of oncology: A multi-center study. Psycho-Oncology, 17 (11), 1089-1099. doi: 10.1002/pon.1330 
Gruber, H., Rose, J. P., Mannheim, E., Weis, J. (2011). Künstlerische Therapien in der Onkologie-wissenschaftlicher Kenntnisstand und Ergebnisse einer Studie: Expressive Arts Therapies in Oncology-Current Research and Study Findings. Musiktherapeutische Umschau, 32 (3), 206-218.

Henn, W., Gruber, H. (2004). Kunsttherapie in der Onkologie. Köln: Richter.

Laridon-Valentini, F., Mouawad, R., Mateescu, C., Spano, J. P., Khayat, D. (2015). 1557 Impact of art therapy on the quality of life of cancer patients: The Salpetriere hospital experience. European Journal of Cancer, $51, \mathrm{~S} 223$.

Lefèvre, C., Ledoux, M., Filbet, M. (2016). Art therapy among palliative cancer patients: Aesthetic dimensions and impacts on symptoms. Palliative \& Supportive Care, 14 (4), 376-380. doi: 10.1017/S1478951515001017

Lin, M. H., Moh, S. L., Kuo, Y. C. et al. (2012). Art therapy for terminal cancer patients in a hospice palliative care unit in Taiwan. Palliative \& Supportive Care, 10 (1), 51-57.

Luzzatto, P., Sereno, V., Capps, R. (2003). A communication tool for cancer patients with pain: The art therapy technique of the body outline. Palliative and Supportive Care, 1(2), 135-142.

Monti, D. A., Peterson, C., Kunkel, E. J. S. et al. (2006). A randomized, controlled trial of mindfulness-based Art Therapy (MBAT) for women with cancer. Psycho-Oncology, 15 (5), 363-373.

Öster, I., Svensk, A.-C., Magnusson, E. et al. (2006). Art therapy improves coping resources: A randomized, controlled study among women with breast cancer. Palliative \& Supportive Care, 4 (1), 57-64.

Reynolds, F., Prior, S. (2006). The role of art making in identity maintenance: Case studies of people living with cancer. European Journal of Cancer Care, 15 (4), 333-341.

Rhondali, W., Lasserre, E., Filbet, M. (2013). Art therapy among palliative care in patients with advanced cancer. Journal of Palliative Medicine, 27 (6), 571-572.

Sinapius, P. (2009). So möchte ich sein. In Krankheitsbewältigung bei Krebs - Bilder aus der Kunsttherapie. Köln: Richter.

Sinapius, P. (2013). Wie ist es, eine Farbe zu sein? Über Kunst und Liebe, das Schweigen und die.

Svensk, A. C., Öster, I., Thyme, K. E. et al. (2009). Art therapy improves experienced quality of life among women undergoing treatment for breast cancer: A randomized controlled study. European Journal of Cancer Care, 18 (1), 69-77.

Vollmer, T., Staroszynski, T. (2004). Kunsttherapie und Krankheitsverarbeitung in der onkologischen Akutklinik. In W. Henn, H. Gruber, Kunsttherapie in der Onkologie. Köln: Richter. P. 71-80.

Weis, J. (2002). Leben nach Krebs: Belastung und Krankheitsverarbeitung im Verlauf einer Krebserkrankung. Bern: Huber.

Wood, M. J. M., Molassiotis, A., Payne, S. (2011). What research evidence is there for the use of art therapy in the management of symptoms in adults with cancer? A systematic review. Psycho-Oncology, 20 (2), 135-145.

Wormit, A. F. (2008). Heidelberger Musiktherapiemanual: Tumor-, Schmerz-und Nierenerkrankungen. Berlin: Uni-Ed. 


\section{MENO TERAPIJA ONKOLOGIJOS IR PALIATYVIOSIOS \\ PRIEŽIŪROS SRITYJE - EMPIRINIŲ REZULTATŲ \\ APŽVALGA IR ATVEJIO ANALIZE்}

\section{Harald Gruber}

Alano dailès ir socialiniu moksly universitetas, Vokietija

\section{SANTRAUKA}

Tyrimo pagrindimas. Psichoterapinių intervencijų spektre meninès terapijos, tokios kaip tapyba, modeliavimas iš molio, muzika, šokio terapija, taip pat poezija ir biblioterapija tapo esmine psichosocialinio gydymo dalimi tarp ịvairių medicininių ir terapinių indikacijų. Meno terapija leidžia ligoniams išreikšti stresines emocijas saugioje aplinkoje, reguliuoti savo patirtį, sužinoti apie išteklius ir geriau apdoroti psichologiškai ribojančias ligos pasekmes. Daugelyje meno terapijos sričių vis dar trūksta empirinio tyrimo efektyvumo ịrodymų. Visgi pastaruoju metu iš dalies kontroliuojami atsitiktinių imčių meno terapijos tyrimai onkologijos srityje rodo akivaizdų ligonių nerimo ir depresijos sumažejimą, mažesnị patiriamą stersą, pagerẻjusị sveikatos suvokimą ir geresnị ligos valdymą. Atvejo analizė rodo, kad darni meno patirtis gali turèti gydomaji poveikị ir yra svarbi ligoniui.

Išvada. Meno terapija, ypač onkologijos ir paliatyviosios priežiūros srityje, pagerina gydymą ir padeda įvykdyti pagrindinius bendro gydymo tikslus. Todèl reikia tolesnio praktinio ir mokslinio pagrindimo, taip pat gerų viešujų ryšių, siekiant atkreipti dèmesi i meno terapijos efektyvumą bei toliau ji plètoti ir patvirtinti kaip pastovų terapinį komponentą onkologijos ir paliatyviosios medicinos srityje, tiek gydant ligonị stacionariai, tiek ambulatoriškai.

Raktažodžiai: meno terapija, onkologija, paliatyvioji slauga, atvejo analizè. 